\title{
Mouse Models of Rheumatoid Arthritis for Studies on Immunopathogenesis and Preclinical Testing of Fc Receptor-Targeting Biologics
}

\author{
Bonnie J.B. Lewis ${ }^{a}$ b Donald R. Branch ${ }^{a, b}, c$ \\ aDepartment of Laboratory Medicine and Pathobiology, University of Toronto, Toronto, ON, Canada; ${ }^{b}$ Centre \\ for Innovation, Canadian Blood Services, Toronto, ON, Canada; 'Department of Medicine, University of Toronto, \\ Toronto, ON, Canada
}

\section{Keywords}

Rheumatoid arthritis - Mouse model · Crystallizable fragment gamma receptor - Intravenous immunoglobulin • Recombinant crystallizable fragment $\cdot r F c$ multimers

\begin{abstract}
Background: Rheumatoid arthritis (RA) is a chronic autoimmune disease that causes inflammation, swelling, and pain in the joints and involves systemic complications. Mouse models of RA have been extensively used to model the pathogenesis of RA and to develop effective therapies. Although many components of the immune system have been studied in these models, the role of crystallizable fragment (Fc) gamma receptors (FcyRs) in RA has been sorely neglected. The aim of this review was to introduce the different mouse models of RA and to describe the different drug development strategies that have been tested in these models to target FcyR function, with the focus being on drugs that have been made from the Fc of immunoglobulin G (IgG). Summary: Evidence suggests that FcyRs play a major role in immune complex-induced inflammation in autoimmune diseases, such as RA. However, there is limited knowledge on the importance of FcyRs in the human disease even though there has been extensive work in mouse models of RA. Numerous mouse models of RA are available, with each model depicting certain aspects of the disease. Induced models of
\end{abstract}

RA have nonspecific immune activation with cartilage-directed autoimmunity, whereas spontaneous models of RA develop without immunization, which results in a more chronic form of arthritis. These models have been used to test FcyR-targeting monoclonal antibodies, intravenous immunoglobulin (IVIg), subcutaneously administered IVIg, and recombinant Fcs for their ability to interact with and modify FcyR function. Recombinant Fcs avidly bind FcyRs and exhibit enhanced therapeutic efficacy in mouse models of RA. Key Message: The therapeutic utility of targeting FcyRs with recombinant Fcs is great and should be explored in human clinical trials for autoimmune diseases, such as RA.

(c) 2020 The Author(s)

Published by S. Karger AG, Basel

\section{Introduction}

Rheumatoid arthritis (RA) is a chronic inflammatory autoimmune disease that primarily affects the joints of the hands and feet but can affect other joints and commonly involves systemic complications [1]. RA is a form of polyarthritis that affects the joints symmetrically. It is characterized by synovitis and synovial hyperplasia, cartilage and bone erosion, as well as systemic inflammation $[2,3]$. This chronic inflammation and progressive tissue destruction lead to irreversible structural deformities and the eventual loss of function of the affected joints [4]. karger@karger.com www.karger.com/pha

Karger $\frac{1}{\%}$

BOPEN ACCESS
(C) 2020 The Author(s)

Published by S. Karger AG, Basel

This article is licensed under the Creative Commons AttributionNonCommercial-NoDerivatives 4.0 International License (CC BYNC-ND) (http://www.karger.com/Services/OpenAccessLicense) Usage and distribution for commercial purposes as well as any distribution of modified material requires written permission.
Dr. Donald R. Branch

Centre for Innovation, Canadian Blood Services

67 College St.

Toronto, ON M5G 2M1 (Canada)

don.branch@utoronto.ca 
Animal models have been used extensively in studies of RA pathogenesis and have contributed to the development of several therapies [5-7]. Our understanding of the importance of pro-inflammatory cytokines, the adaptive immune system, autoantibodies, and crystallizable fragment $(\mathrm{Fc})$ gamma receptors $(\mathrm{Fc} \gamma \mathrm{Rs})$ in the pathogenesis of RA is due to studies in mouse models [8-14]. Monoclonal antibody therapies have been successfully developed in mouse models of RA. For example, infliximab is a monoclonal antibody that targets tumor necrosis factor-alpha (TNF- $\alpha$ ) [8]. It has long been known that TNF- $\alpha$ plays a significant role in cartilage and bone erosion in RA because transgenic mice expressing human TNF- $\alpha$ experience a severe and erosive form of polyarthritis $[8,15]$. Treatment of these arthritic mice with infliximab completely abrogates the disease [8]. Furthermore, the success of B-cell depletion therapy with rituximab, an anti-CD20 monoclonal antibody, was corroborated in both the collagen-induced arthritis (CIA) model and in $\mathrm{K} / \mathrm{BxN}$ mice, which spontaneously develop arthritis $[16,17]$.

Although both mouse models and human studies have elucidated the importance of $\mathrm{Fc} \gamma \mathrm{Rs}$ in the pathogenesis of $\mathrm{RA}$, these receptors have not been given the attention they deserve [18-21]. In RA, autoantibodies and immune complexes promote an inflammatory response by engaging Fc $\gamma$ Rs. This engagement can lead to a multitude of responses such as pro-inflammatory cytokine release, antibody-dependent cellular cytotoxicity (ADCC), phagocytosis, and respiratory burst. These responses lead to sustained inflammation and tissue destruction within the joint. Disrupting this interaction has been explored through multiple avenues such as monoclonal antibodies [22, 23], intravenous immunoglobulin (IVIg) $[24,25]$, and through the development of recombinant Fcs that are composed of the of immunoglobulin G (IgG) [26]. These proteins could potentially treat autoimmune diseases because of their ability to produce a range of different immunomodulatory effects [27]. This review provides an overview of the different mouse models of RA, and it discusses the use of different recombinant Fcs in these models to highlight the therapeutic utility of targeting Fc $\gamma$ Rs in RA.

\section{Fc Receptors}

Fc receptors are proteins expressed on the surface of myeloid cells, B cells, NK cells, NKT cells, and certain subsets of $\mathrm{T}$ cells that interact with the Fc of Igs as described in a thorough review of the topic [28]. Fc receptors are the link between antibodies and the innate im-

Animal Models of RA Used to Assess

Treatment Modalities mune system. They can activate or inhibit cells, cause the release of pro-inflammatory cytokines, and they also participate in ADCC and phagocytosis [29]. Fc $\gamma$ Rs are part of a family of $\mathrm{Fc}$ receptors that recognize the Fc of IgG [28]. For human IgG, the activating receptors are $\mathrm{Fc} \gamma \mathrm{RI}$, Fc $\gamma$ RIIA, Fc $\gamma$ RIIC, Fc $\gamma$ RIIIA, and Fc $\gamma$ RIIIB [28]. Fc $\gamma$ RI is a high-affinity activating receptor that binds monomeric IgG, whereas Fc $\gamma$ RII and $\mathrm{Fc} \gamma \mathrm{RIII}$ are low-affinity activating receptors that only bind aggregated IgG or immune complexes [28]. For mouse IgG, Fc $\gamma$ RI, Fc $\gamma$ RIII, and $\mathrm{Fc} \gamma \mathrm{RIV}$ are the activating receptors [28]. $\mathrm{Fc} \gamma \mathrm{RI}$ is also a high-affinity activating receptor in mice, whereas Fc $\gamma$ RIII and $\mathrm{Fc} \gamma \mathrm{RIV}$ are low-affinity activating receptors [28]. For both human and mouse IgG, Fc $\gamma$ RIIB is the only inhibitory receptor [28]. In humans and mice, monocytes, macrophages, dendritic cells, and neutrophils express all types of activating $\mathrm{Fc} \gamma \mathrm{Rs}$ and the inhibitory $\mathrm{Fc} \gamma \mathrm{R}$, whereas B cells only express Fc $\gamma$ RIIB [28].

The activating Fc $\gamma$ Rs have a cytoplasmic immunoreceptor tyrosine-based activation motif (ITAM), while the inhibitory $F_{c} \gamma R$ has an immunoreceptor tyrosinebased inhibitory motif [28]. Initiation of the activation pathway leads to the phosphorylation of ITAM sequences by Src-family kinases, which recruits and activates the spleen tyrosine kinase. This results in the activation of downstream signaling pathways that are important for cellular proliferation, cytokine and chemokine production, ADCC, phagocytosis, and respiratory burst [21]. Initiation of the inhibitory pathway leads to the phosphorylation of immunoreceptor tyrosine-based inhibitory motif sequences, which prevents cellular proliferation, cytokine and chemokine production, ADCC, phagocytosis, and respiratory burst through the recruitment of Src-homology 2 domain tyrosine phosphatases, SHIP or SHP [21]. The crosslinking of Fc $\gamma$ Rs by $\operatorname{IgG}$ is critical for these downstream signaling pathways to occur [21]. Different IgG isotypes bind with different affinities to activating and inhibitory $F_{c} \gamma$ Rs, which can skew the activation/inhibition ratio toward cellular activation or inhibition [29]. The disequilibrium between activating and inhibitory $\mathrm{Fc} \gamma \mathrm{Rs}$ can result in uninhibited inflammatory responses, such as those seen in RA. Further understanding of this threshold of activation will promote the development of new therapeutic strategies that target $\mathrm{F} c \gamma$ Rs.

\section{FcyRs in the Pathogenesis of RA}

Evidence suggests that $\mathrm{Fc} \gamma \mathrm{Rs}$ play a major role in immune complex-induced inflammation in autoimmune diseases such as RA. During normal immune responses, the 
Fc $\gamma$ R-mediated antibody effector functions are fine-tuned by a balance between activating and inhibitory Fc $\gamma$ Rs. However, this balance is skewed toward activating functions of Fc $\gamma$ Rs in autoimmunity, which reduces the threshold for immune complex-mediated activation of inflammatory cells $[19,30]$. In RA, this disequilibrium is caused by an upregulation of activating Fc $\gamma$ Rs, which lowers the threshold for monocyte/macrophage activation, which are major contributors of inflammation and tissue damage [31].

Increases in the expression of activating $\mathrm{Fc} \gamma \mathrm{Rs}$ have been found on the peripheral blood monocytes of RA patients, and this correlates with inflammatory serological markers, such as erythrocyte sedimentation rate [32]. Additionally, treatment-naive RA patients had significantly higher levels of activating Fc $\gamma$ RIIA on their monocytes, macrophages, and NK cells in comparison to RA patients taking disease-modifying anti-rheumatic drugs. This suggests that there is a correlation between activating $\mathrm{Fc} \gamma \mathrm{R}$ expression and disease activity $[32,33]$.

Several other studies have showed the importance of activating $\mathrm{F} c \gamma \mathrm{Rs}$ in patients with RA. In one study, monocytes from RA patients secreted TNF- $\alpha$, interleukin (IL)- $1 \beta$, and IL-8 upon stimulation with immobilized immune complexes. The release of these pro-inflammatory cytokines was inhibited by blocking Fc $\gamma$ RIIA with a monoclonal antibody [34]. In another study, immune complexes that were isolated from the synovial fluid of RA patients induced the same response from monocytes, which was also blocked by a monoclonal antibody to Fc $\gamma$ RIIA [35]. These results were reproduced in healthy subjects; the stimulation of healthy monocytes and macrophages with immune complexes formed by anti-citrullinated protein antibodies from RA patient sera or synovial fluid resulted in TNF-a secretion via engagement of Fc $\gamma$ RIIA $[31,35,36]$. When the RA synovium was compared with a healthy synovium, there was increased expression of activating $\mathrm{Fc} \gamma \mathrm{Rs}$ in the RA synovium, and this correlated with an increased number of synovial macrophages that expressed TNF- $\alpha[37,38]$.

Thus, $F_{c} \gamma$ Rs are potential targets for the treatment of antibody-mediated autoimmune diseases.

\section{Targeting FcyRs}

Historically, Fc $\gamma$ Rs have been blocked with mouse antihuman monoclonal antibodies that target the IgG-binding site of $\mathrm{Fc} \gamma \mathrm{Rs}$, as well as with IVIg. More recently, recombinant Fcs derived from the Fc of IgG have been used to block autoantibody and immune complex engagement with $\mathrm{F} c \gamma \mathrm{Rs}$ to prevent a range of cellular responses.

\section{Anti-FcyR Monoclonal Antibodies}

Monoclonal antibodies directed against $\mathrm{F} c \gamma \mathrm{Rs}$ have been used to block immune complex-mediated activation of these receptors. Mouse antihuman monoclonal antibodies have been made against each of the activating and inhibitory $\mathrm{F} c \gamma \mathrm{Rs}[39,40]$. The mouse monoclonal antibody 3G8 targets human Fc $\gamma$ RIII and has been used in humans to block the clearance of antibody-coated platelets in patients with immune thrombocytopenia (ITP) $[41,42]$. ITP is an autoimmune disease whereby platelets are targeted by the humoral system and destroyed through $\mathrm{F} c \gamma \mathrm{R}$-mediated phagocytosis in the spleen and liver [43]. 3G8 successfully prevented platelet loss in human clinical trials for ITP [43]. The high-affinity Fc $\gamma$ RI has also been targeted by monoclonal antibodies in clinical trials for ITP. Monoclonal antibody 197 abrogated IgG binding to $\mathrm{Fc} \gamma \mathrm{RI}$, and it modulated the expression of $\mathrm{Fc} \gamma \mathrm{RI}$ in humans [44].

Although the role of Fc $\gamma$ RIII in human ITP is apparent, the role of this $F c \gamma R$ and others has not been elucidated in more complex autoimmune diseases, such as RA. There are significant challenges when selecting which Fc $\gamma$ Rs to target in RA because leukocytes express several $\mathrm{Fc} \gamma \mathrm{Rs}$ at the same time. It is not clear which $\mathrm{F} c \gamma \mathrm{Rs}$ on which cell types are involved in the pathogenesis of RA and whether there is redundancy between $\mathrm{F} c \gamma \mathrm{Rs}$ or whether some $\mathrm{F} c \gamma \mathrm{Rs}$ are more important than others. Thus, the development of anti-Fc $\gamma \mathrm{R}$ monoclonal antibodies for the treatment of complex autoimmune diseases in humans has been limited.

\section{Intravenous Immunoglobulin}

IVIg is the pooled plasma from tens of thousands of donors and it is mainly composed of polyvalent IgG antibodies, with trace amounts of IgA and IgM [45-47]. IVIg was initially indicated to treat primary immunodeficiency; however, it is now used as a therapy for several autoimmune diseases and inflammatory conditions [48, 49]. Additionally, high-dose IVIg has become a first-line therapy for autoimmune diseases such as ITP and Kawasaki disease [50,51]. IVIg was first given at a high dose of $400 \mathrm{mg} / \mathrm{kg}$ over 5 consecutive days to raise platelet counts in pediatric patients with ITP [52]. Later, it was found to be effective in treating adult ITP with over $80 \%$ of patients responding to IVIg shortly after treatment [53-57].

There are several mechanisms of action that have been proposed for the immunomodulatory effects of IVIg; how- 
ever, this topic is still heavily debated [57]. One of the earliest proposed mechanisms of IVIg includes the blockade of activating Fc $\gamma$ Rs on macrophages by IVIg $[56,58]$. Fehr et al. [56] showed that the clearance of radiolabeled erythrocytes was delayed by IVIg administration, suggesting that IVIg worked to treat ITP by blocking Fc $\gamma$ Rs on macrophages and inhibiting platelet clearance. This theory was corroborated by Salama et al. [59] who showed that there was increased hemolysis after IVIg therapy. Additional evidence for the involvement of $\mathrm{Fc} \gamma \mathrm{Rs}$ was demonstrated by Aloulou et al. [60] who showed that binding of IVIg to Fc $\gamma$ RIIIA induced inhibitory ITAM signaling and contributed to the anti-inflammatory activity of IVIg. There is also evidence showing a role for the antibody-binding Fab region of IVIg in its immunomodulatory effects. Investigators have shown that the antigen-binding fragments $\left(F\left[\mathrm{ab}^{\prime}\right] 2\right)$ of IVIg could ameliorate ITP in human patients [61, 62]. In addition, anti-Siglec-8 autoantibodies found in IVIg preparations were shown to have anti-inflammatory effects [63, 64]. One group found that sialyation of the Fab, not the Fc, was associated with the anti-inflammatory activity [65].

The main hypotheses as to how IVIg works as an antiinflammatory biologic come from the group at the Rockefeller University headed by Jeffrey Ravetch [66-68]. One theory proposed involves the upregulation of inhibitory Fc $\gamma$ RIIB on effector cells, which increases their threshold for activation [66, 68]. Using an antibody-induced passive mouse model of ITP in Fc $\gamma$ RI, Fc $\gamma$ RIIB, and Fc $\gamma$ RIII knockout mice, Samuelsson et al. [66] showed that IVIg reduced platelet clearance through the concurrent inhibition of Fc $\gamma$ RIII with the upregulation of Fc $\gamma$ RIIB. Additionally, IVIg was shown to be ineffective at treating ITP in Fc $\gamma$ RIIB knockout mice [66]. However, other investigators could not replicate this work [69]. One study found that IVIg specifically downregulated activating Fc $\gamma$ RIIIA on $\mathrm{CD} 11 \mathrm{c}^{+}$dendritic cells, which had no effect on Fc $\gamma$ RIIB expression [69]. Other studies showed that Fc $\gamma$ RIIB was unnecessary for IVIg efficacy using different strains of Fc $\gamma$ RIIB knockout mice [69-72].

In accordance with their theory that IVIg upregulates Fc $\gamma$ RIIB as part of its mechanism, Ravetch et al. [73] proposed that the $\mathrm{Fc} \gamma$-sialylated fraction of IgG is responsible for the immunomodulatory properties of IVIg [24, 73-75]. This model proposed that a small fraction (10\%) of total IVIg sialylated in the $\mathrm{F} c \gamma$ domain engages the cluster of differentiation 209, also known as DC-SIGN, on regulatory macrophages and dendritic cells, which causes them to release IL-33 [68, 75]. IL-33 is a Th2-polarizing cytokine that would then promote the release of IL-4 from basophils at sites of inflammation. IL-4 acts on

Animal Models of RA Used to Assess

Treatment Modalities macrophages to upregulate the expression of Fc $\gamma$ RIIB, which lowers inflammation [68]. This model proposes that the subsequent upregulation of Fc $\gamma$ RIIB on effector cells raises their threshold for activation, thus allowing for a reduction in inflammation $[67,68,75]$.

However, this model has not been supported by other investigators. Despite a recent report that IVIg induces IL-4 in human basophils, which supports the "Ravetch model" [76], other investigators have shown that although IL- 4 is induced by IVIg treatment in mouse models [77], neither IL-4 nor basophils are required for the anti-inflammatory effects of IVIg [78-80]. In addition, although a recent report indicates that Fc sialylation may play a role in the mechanism of action of IVIg in certain conditions [81], other groups have not been able to confirm a role for Fc sialyation [82-86]. Additional studies also suggest that there is not a role for either DC-SIGN [87] or IL-33 $[77,88]$ in the anti-inflammatory mechanism of IVIg. These discrepancies between the model of IVIg action proposed by the Ravetch group and the findings by other scientists in the field led to a rebuttal article by von Gunten et al. [89] published in 2014.

Other possible mechanisms of action of IVIg have been proposed. Production of prostaglandin E2 (PGE2) by IVIg binding to dendritic cells, which then induces an increase in T-regulatory cells has been reported $[90,91]$. Also, it was recently published that IVIg induces autophagy which regulates the inflammatory response [92]. A definitive mechanism for the anti-inflammatory activity induced by IVIg awaits resolution. Its mechanism of action appears complicated, and it may work differently depending on the autoimmune model that is used.

\section{Limitations of IVIg}

IVIg is generally considered to be a safe drug because it has minimal side effects and most of these side effects are benign, with chills and headaches being most common. More serious adverse events such as thrombosis and hemolysis are very rare [93-99]. IVIg also has a very favorable safety profile because it is immunomodulatory rather than immunosuppressive.

Despite this, there are serious challenges associated with the manufacturing and application of this drug. First, the manufacturing of IVIg requires highly specialized production facilities, which are very expensive to maintain [100]. Patients who receive IVIg are at risk of contracting blood-borne pathogens, particularly newly emerging infections, so careful attention must be paid to 
pathogen safety. Not only is the cost of these production facilities expensive, but IVIg itself is very expensive because its supply is dependent on the availability and the collection of human plasma. With an increase in the demand for IVIg to treat a variety of autoimmune and inflammatory conditions and a decrease in the supply of human plasma donations, the price of IVIg has drastically increased to pay for the high doses required for immunomodulation [101].

\section{IVIg in RA}

IVIg has been increasingly used for the treatment of patients with autoimmune and inflammatory diseases, such as ITP, Guillain-Barré syndrome, Kawasaki disease, and several other rare diseases [102]. Additionally, IVIg is used off-label in many other diseases and is currently under evaluation for the treatment of RA [103].

However, there is a limited amount of research performed on the therapeutic efficacy of IVIg in RA [104108]. The human trials that were done to evaluate this were not controlled and were performed in the prebiologic era; thus, the results were equivocal [104-108]. Additionally, the patient cohort for these studies was small, with some studies having less than 20 patients enrolled $[108,109]$. A high-dose IVIg protocol of $1-2 \mathrm{~g} / \mathrm{kg}$ of IVIg per month for a minimum of 6 months is critical for effectively treating systemic autoimmune diseases [47]. However, these studies used lower doses of $400 \mathrm{mg} / \mathrm{kg}$ of IVIg without any long-term follow-up [108, 109].

There has been an increasing amount of evidence that IVIg works to treat RA in various mouse models through the Fc $\gamma$ R blockade [22, 89, 110-112]. However, the numerous challenges associated with IVIg production and its application has provided incentives to develop an alternative therapy with similar efficacy but with improved characteristics. This particularly applies for indications where the effector mechanism(s) of IVIg are dependent on the Fc of IgG. The mechanism of IVIg in mouse models of RA has been proposed to be mediated by the Fc of IgG $[22,89$, 110-112]. Accordingly, many researchers have investigated recombinant Fcs as a replacement for IVIg.

\section{Mouse Models of RA}

Several mouse models have progressed our understanding of the immunopathogenesis of RA and have contributed to the development of several therapies. Most of these mouse models have a role for $\mathrm{Fc} \gamma \mathrm{Rs}$ in their pathogenesis and are being used to investigate recombinant Fcs as a replacement for IVIg.

\section{Induced Mouse Models of RA}

The CIA mouse model is the gold standard in vivo model for RA because its pathological features closely resemble those in humans $[113,114]$. CIA is a form of polyarthritis with synovial inflammation, cartilage destruction, and bone erosion [113]. In CIA, susceptible mouse strains such as DBA/1, B10.Q, and B10.RIII DBA/1 are immunized against type II collagen (CII) in complete Freund's adjuvant $[114,115]$. The clinical signs of arthritis usually appear 3-5 weeks after immunization [115, 116]. The pathogenesis of CIA is dominated by Th1 and Th17 cells, which provide B-cell help such that autoantibodies to CII are made [117].

The collagen antibody-induced arthritis (CAIA) mouse model represents the effector phase of arthritis $[118,119]$. A cocktail of anti-CII monoclonal antibodies is administered to induce arthritis in mice [120]. LPS is used to enhance the incidence and severity of the arthritis. There are many susceptible mouse strains that can be used for this model, and the clinical signs of arthritis generally appears a few days after antibody administration [121]. Immune complexes initiate inflammation by activating the classical complement pathway or by engaging Fc $\gamma$ Rs on immune cells [119, 121-123].

\section{Spontaneous Mouse Models of RA}

Human TNF- $\alpha$-transgenic mice spontaneously develop arthritis [124]. After 3-4 weeks of age, synovial hyperplasia and inflammatory cell infiltrates are observed in the joint, and at around 10 weeks of age, the mice exhibit pannus formation, cartilage destruction, and bone erosion [125]. Synovial fibroblasts are the main drivers of arthritis in this model, rather than immune cells [126]. This model elucidated the importance of TNF- $\alpha$ in the pathogenesis of arthritis and was instrumental in the development of TNF inhibitors [124].

IL-1 receptor antagonist knockout mice also develop spontaneous arthritis. Interestingly, these mice generate antibodies against CII, double-stranded DNA, and IgM RF [9]. After 5 weeks of age, synovial inflammation ensues, and at 8 weeks of age, mice experience higher rates of morbidity. Given the fact the anti-IL- $1 \beta$ therapies such as Anakinra, a molecule targeting the human IL-1 receptor antagonist, have only worked in a minor subset of RA patients; this mouse model is not commonly used to study this disease [127]. 
$\mathrm{K} / \mathrm{BxN}$ mice also develop arthritis spontaneously. K/ $\mathrm{BxN}$ mice are made by crossing T-cell receptor (TCR)transgenic KRN mice with nonobese diabetic mice [105]. Arthritis progression in $\mathrm{K} / \mathrm{BxN}$ mice is driven by the activation of T cells expressing the KRN TCR that recognizes a self-peptide bound to the nonobese diabetic-derived $\mathrm{MHC}$ class II I-Ag7 molecule on antigen-presenting cells [128]. The peptide recognized by the $\mathrm{K} / \mathrm{BxN}$ TCR is glucose-6-phosphate isomerase (G6PI), a cytosolic glycolytic enzyme catalyzing the inter-conversion of d-glucose-6-phosphate to d-fructose-6-phosphate [13, 129]. Pathogenic autoantibodies to G6PI are created when activated $\mathrm{T}$ cells give help to $\mathrm{B}$ cells through CD40:CD40ligand (L) engagement $[12,13,127-131]$. The serum from $\mathrm{K} / \mathrm{BxN}$ mice contains anti-G6PI autoantibodies and, thus, can be transferred to a variety of mouse strains, including B- and T-cell-deficient mice, to induce arthritis $[12,130,131]$. This arthritis lasts for $\sim 2-4$ weeks; however, repeated administration of the serum can prolong the arthritis $[132,133]$.

Many researchers use the $\mathrm{K} / \mathrm{BxN}$ serum transfer model to study arthritis even though there is no breach in tolerance. Although this model is a useful tool to understand how autoantibodies drive the progression of arthritis by interacting with downstream components of the innate immune system, there are some major differences between the serum transfer model and the human disease. These include differences in antibody specificities and function, and differences in immune cells that drive pathogenesis $[12,13]$. Considering this, studies have been done to treat $\mathrm{K} / \mathrm{BxN}$ mice endogenously because the immune cells involved in driving the inflammatory response in $\mathrm{K} / \mathrm{BxN}$ mice more tightly mimic those experienced in the human disease [110].

\section{Recombinant Fcs Successfully Ameliorate RA in Mouse Models}

Many researchers have investigated recombinant Fcs as a replacement for IVIg. First, monomeric Fc derived from the plasma of donors successfully treated autoimmune diseases such as ITP and Kawasaki disease [134, 135]. However, there were issues that arose from the small molecular weight of these plasma-derived Fcs, such as rapid clearance from the body. Additionally, these potential replacements did not resolve the issues associated with obtaining human plasma. Researchers focused on the future of immunoglobulin-based therapies [136, 137], and this has led to the recent development of recombinant Fcs $[26,27,138,139]$. This alternative would preclude the use of human plasma.

Many strategies have been used to multimerize the Fc of IgG in order to produce polyvalent Fc molecules [26, $27,138,139]$. First, stradomers were made through the fusion of the human IgG2 hinge region to human IgG1 Fc or to mouse IgG2a Fc [140]. This led to the production of stradomerized Fcs that bound Fc $\gamma$ Rs with high avidity [141]. These stradomers demonstrated therapeutic efficacy in the CIA model and in animal models of ITP, inflammatory neuropathy, and myasthenia gravis [141143]. Importantly, efficacy was achieved at approximately 20-40-fold lower doses than IVIg.

A trivalent multimer was also made and compared to multimers with increasing and decreasing valences [144]. The trimer, M230, was composed of 3 IgG1 Fcs that were stabilized by "knobs-into-holes" technology developed by Ridgway et al. [145] in 1996. This study showed that any molecule with a valency greater than 3 bound $F c \gamma$ Rs with high avidity and initiated activating signals, whereas any molecule with a valency of 3 or less bound $F c \gamma$ Rs with high avidity without triggering activating signals [144]. Results from both the CIA and the CAIA models showed that M230 was more efficacious than IVIg at 10-fold lower doses [144]. In the ITP mouse model, it was most effective as it raised platelet counts at 100 -fold lower doses than IVIg [144]. Additionally, M230 ameliorated epidermolysis bullosa acquisita at doses as low as $25 \mathrm{mg} / \mathrm{kg}$ [144]. This study addressed the importance of monitoring adverse events after multimeric Fc administration. Like immune complexes, Fc multimers can crosslink $\mathrm{F} c \gamma \mathrm{Rs}$ and lead to subsequent activation. The consequences of this would be a severe inflammatory response, which would ultimately be counterintuitive to the objective of treatment with the Fc.

A hexameric-Fc molecule called HexaGard was developed using the technology developed by Smith et al. [146] who showed that the addition of the C-terminal 18 aa tailpiece of IgM lead to hexamerization of IgG. This technology was applied to hexamerize human IgG1 Fcs to form HexaGard [147]. HexaGard showed high avidity for Fc $\gamma$ Rs and for cluster of differentiation 209 and showed efficacy in a mouse model of ITP. However, future studies on HexaGard were discontinued because it appeared to have unwanted side effects, such as the activation of complement through its enhanced avidity to $\mathrm{C} 1 \mathrm{q}$, which lead to C5b-9 deposition [147].

In addition to HexaGard, multiple hexameric-Fc fusion proteins were engineered to be tested in multiple in 
vitro and in vivo systems to determine the consequences of multivalent $\mathrm{Fc} \gamma \mathrm{R}$ engagement [148]. One hexamericFc was composed of an IgG4 and IgG1 entitled $\gamma 4$ enghexameric-Fc. The second hexameric-Fc was a mutant version of this protein containing L234F/P331S mutations to reduce platelet and complement activation, entitled $\gamma 1$ eng-hexameric-Fc. Finally, the third hexamericFc was another mutant which had F234L/F296Y mutations introduced to increase its ability to block Fc $\gamma$ Rdependent phagocytosis, entitled $\gamma 4$ eng-F234L F296Y hexameric-Fc [149].

The major finding of this study was that the hexameric-Fcs bound avidly to Fc $\gamma$ Rs, and this interaction caused the rapid internalization of these hexameric-Fcs and the subsequent degradation of activating but not inhibitory Fc $\gamma$ Rs. This effect was prolonged and occurred in both in vitro and in vivo systems. This effect disrupted $\mathrm{Fc} \gamma \mathrm{R}$ function and lead to the potent inhibition of phagocytosis. The hexameric-Fcs were further tested in a mouse model of ITP and were found to be effective at protecting platelets from phagocytic degradation for a prolonged period. This study highlighted the therapeutic utility for hexameric-Fcs in diseases involving $\mathrm{Fc} \gamma \mathrm{R}$-mediated phagocytosis, such as ITP. However, this study also highlighted the potential challenges for the clinical development of hexameric-Fc-based therapeutics because of their rapid clearance in in vivo systems.

More recently, much attention has been given to a recombinant human IgG1 Fc multimer, GL-2045 [138143]. GL-2045 is composed of the human IgG1 Fc with its C-terminus fused to the human IgG2 hinge region to facilitate the formation of stradomers [150, 151]. When this molecule was first designed, it was shown to be a potent inhibitor of complement activation [151]. However, a more recent article published by the same group focused on its potential as a replacement for IVIg for the treatment of IgG-mediated autoimmune diseases because of its ability to efficiently mimic the anti-inflammatory and immunomodulatory properties of Ig Fc aggregates [111].

The article [111] showed that GL-2045 was more efficient at blocking the binding of immune complexes from patients with RA to $\mathrm{Fc} \gamma \mathrm{Rs}$, and it was more efficient at inhibiting phagocytosis in comparison to IVIg. Additionally, GL-2045 efficiently ameliorated ITP in a mouse model, and both prevented and suppressed arthritis in the CIA model. GL-2045 also reduced the systemic levels of potent inflammatory cytokines such as IL-6. As of 2018, GL-2045 has been in phase 1 clinical trials for the treatment of unspecified autoimmune diseases.
Two hexameric recombinant $\mathrm{Fc}$ molecules entitled Fc$\mu \mathrm{TP}$ and Fc- $\mu \mathrm{TP}-\mathrm{L} 309 \mathrm{C}$ were designed as potential replacements for IVIg [152]. Fc- $\mu$ TP was generated by fusing the 18 aa residues of the human IgM tailpiece to the $\mathrm{C}$-terminus of a wild-type human IgG1 Fc, Fc- $\mu$ TP, or a variant with a point mutation changing the leucine residue at position 309 to a cysteine residue, $\mathrm{Fc}-\mu \mathrm{TP}-\mathrm{L} 309 \mathrm{C}$. The same technology that was used to create HexaGard was also used to create Fc- $\mu$ TP and Fc- $\mu$ TP-L309C [148, 149].

This resulted in the formation of 2 recombinant $\mathrm{Fc}$ hexamers, with the point mutations in Fc- $\mu$ TP-L309C, providing a more stable structure than $\mathrm{Fc}-\mu \mathrm{TP}$, because of the formation of disulfide bonds between the Fc molecules [152]. Fc- $\mu$ TP-L309C bound Fc $\gamma$ Rs with high avidity and inhibited $\mathrm{F} c \gamma \mathrm{R}$-mediated effector functions such as ADCC, phagocytosis, and respiratory burst [152]. In addition, $\mathrm{FC}-\mu \mathrm{TP}-\mathrm{L} 309 \mathrm{C}$ prevented full activation of the classical complement pathway by blocking $\mathrm{C} 2$ cleavage, which avoided the generation of inflammatory downstream products such as the potent anaphylatoxin C5a or the membrane attack complex. Fc- $\mu$ TP-L309C suppressed CIA, CAIA, K/BxN serum transfer, and K/ $\mathrm{BxN}$ endogenous arthritis in mice when given therapeutically at approximately a 10-fold lower dose than IVIg $[78,110]$. This was associated with reduced inflammatory cytokine production and complement activation [152].

The potential advantages of replacing IVIg with recombinant Fcs are evident. First, they allow for the reproducible manufacturing of high amounts of recombinant product with consistent quality using processes that are independent of plasma supply. A reduction in the need for plasma would provide massive benefits for healthcare systems because IVIg is expensive to produce and shortages are common. Importantly, the potential for higher efficacy may allow for significantly lower doses for patients such that they could be administered subcutaneously from the comfort of one's home. This could drastically increase the quality of life for patients who receive regular IVIg infusions.

\section{Conclusion}

In addition to RA, there are many other autoantibodymediated autoimmune diseases and their prevalence is increasing worldwide [153-155]. Unfortunately, systemic immunosuppression with steroids is a reality for most patients and they suffer from severe adverse effects, con- 
comitant morbidities, and an increased mortality [156]. Thus, there is a need for the development of novel treatments for patients suffering from autoantibody-mediated autoimmune diseases that do not impose serious negative effects.

Activating $\mathrm{Fc} \gamma \mathrm{Rs}$ initiate and maintain inflammatory responses induced by immune complexes. This has been illustrated in mouse models of RA, such as CIA [157]. Additionally, transgenic mice expressing human Fc $\gamma$ RIIA are highly susceptible to tissue damage by immune complexes, which further implicates $\mathrm{Fc} \gamma \mathrm{Rs}$ as central mediators of inflammation in human disease [158]. In these animal models, immune complex binding to $\mathrm{Fc} \gamma \mathrm{Rs}$ activates inflammatory cells, resulting in pro-inflammatory mediator release and tissue damage [158].

Several studies have reported the importance of activating $\mathrm{Fc} \gamma \mathrm{Rs}$ in patients with RA. Blocking Fc $\gamma$ RIIA engagement with immune complexes from the sera or synovial fluid of RA patients with monoclonal antibodies prevented the release of pro-inflammatory mediators. Thus, $\mathrm{Fc} \gamma \mathrm{Rs}$ are potential targets for the treatment of autoimmune diseases involving pathogenic autoantibodies, and recombinant Fcs is a therapeutic strategy that should be considered.

\section{Acknowledgements}

We acknowledge the financial support from CSL Behring, Research, CSL Biologics Research Center, Bern, Switzerland. We thank Dr. Geraldine Walsh, knowledge broker at the Canadian
Blood Services' Centre for Innovation, for reviewing the manuscript, checking for redundancy, and providing important comments.

\section{Disclosure Statement}

Canadian blood services: employer. Canadian blood services: intramural grant funding. Canadian blood services: U.S. and European patents issued; Canadian patent pending. Health Canada: supplementary funding. CSL Behring: research contracts and INKIND support.

\section{Funding Sources}

CSL Behring, Research, CSL Biologics Research Center, Bern, Switzerland, provided recombinant Fc- $\mu$ TP-L309C and through a research contract with D.R.B., funding to investigate the efficacy and mechanism of action of Fc- $\mu$ TP-L309C in ITP and RA. B.J.B.L. is a recipient of a Canadian Blood Services' Graduate Fellowship Program (GFP) award. Funding was also provided through general resources provided, in part, by Health Canada (D.R.B.). The views expressed herein do not necessarily represent the view of the federal government of Canada.

\section{Author Contributions}

B.J.B.L. is a graduate student who wrote the manuscript and performed specific experiments cited in the manuscript; D.R.B. is the principal investigator who co-wrote and edited the manuscript. The authors satisfy the ICMJE criteria for authorship and have read and approved the manuscript.

\section{References}

1 Smolen JS, Aletaha D, McInnes IB. Rheumatoid arthritis. Lancet. 2016 Oct 22; 388(10055):2023-38.

2 Scott DL, Wolfe F, Huizinga TW. Rheumatoid arthritis. Lancet. 2010;376(9746):1094108.

3 Stoffer MA, Schoels MM, Smolen JS, Aletaha D, Breedveld FC, Burmester G, et al. Evidence for treating rheumatoid arthritis to target: results of a systematic literature search update. Ann Rheum Dis. 2016 Jan;75(7):16-22.

4 Alarcon RT, Fernandes AR, Laurindo IM, Bértolo MB, Pinheiro GC, Andrade LE. Characterization of cumulative joint damage patterns in patients with rheumatoid arthritis: a clinical, serological, and gene polymorphism perspective. J Rheumatol. 2015 Mar;42(3): 405-12.
5 Vincent TL, Williams RO, Maciewicz R, Silman A, Garside P. Mapping pathogenesis of arthritis through small animal models. Rheumatology. 2012 Mar 16;51(11):1931-41.

6 Bevaart L, Vervoordeldonk MJ, Tak PP. Evaluation of therapeutic targets in animal models of arthritis: how does it relate to rheumatoid arthritis? Arthritis Rheum. 2010 Aug;62 (8):2192-205

7 Hegen M, Keith JC, Collins M, NickersonNutter CL. Utility of animal models for identification of potential therapeutics for rheumatoid arthritis. Ann Rheum Dis. 2008 Nov; 67(11):1505-15.

8 Keffer J, Probert L, Cazlaris H, Georgopoulos S, Kaslaris E, Kioussis D, et al. Transgenic mice expressing human tumour necrosis factor: a predictive genetic model of arthritis. EMBO J. 1991 Dec;10(13):4025-31.
9 Horai R, Saijo S, Tanioka H, Nakae S, Sudo K, Okahara A, et al. Development of chronic inflammatory arthropathy resembling rheumatoid arthritis in interleukin 1 receptor antagonist-deficient mice. J Exp Med. 2000 Jan 17; 191(2):313-20.

10 Kadowaki KM, Matsuno H, Tsuji H, Tunru I. $\mathrm{CD} 4+\mathrm{T}$ cells from collagen-induced arthritic mice are essential to transfer arthritis into severe combined immunodeficient mice. Clin Exp Immunol. 1994 Aug;97(2):212-8.

11 Taylor PC, Plater-Zyberk C, Maini RN. The role of the $\mathrm{B}$ cells in the adoptive transfer of collagen-induced arthritis from DBA/1 $(\mathrm{H}-$ 2q) to SCID (H-2d) mice. Eur J Immunol. 1995 Mar;25(3):763-9. 
12 Korganow AS, Ji H, Mangialaio S, Duchatelle V, Pelanda R, Martin T, et al. From systemic $T$ cell self-reactivity to organ-specific autoimmune disease via immunoglobulins. Immunity. 1999 Apr;10(4):451-61.

13 Matsumoto I, Staub A, Benoist C, Mathis D. Arthritis provoked by linked $\mathrm{T}$ and $\mathrm{B}$ cell recognition of a glycolytic enzyme. Science. 1999 Nov 26;286(5445):1732-5.

14 Corr M, Crain B. The role of FcgammaR signaling in the $\mathrm{K} / \mathrm{B} \times \mathrm{N}$ serum transfer model of arthritis. J Immunol. 2002 Dec;169(11):66049.

15 McInnes IB, Schett G. Cytokines in the pathogenesis of rheumatoid arthritis. Nat Rev Immunol. 2007 Jun;7(6):429-42.

16 Yanaba K, Hamaguchi Y, Venturi GM, Steeber DA, St Clair EW, Tedder TF. B cell depletion delays collagen-induced arthritis in mice: arthritis induction requires synergy between humoral and cell-mediated immunity. J Immunol. 2007 Jul 15;179(2):1369-80.

17 Huang H, Benoist C, Mathis D. Rituximab specifically depletes short-lived autoreactive plasma cells in a mouse model of inflammatory arthritis. Proc Natl Acad Sci U S A. 2010 Mar 9;107(10):4658-63.

18 Hogarth PM. Fc receptors are major mediators of antibody based inflammation in autoimmunity. Curr Opin Immunol. 2002 Dec; 14(6):798-802.

19 Takai T. Fc receptors and their role in immune regulation and autoimmunity. J Clin Immunol. 2005 Jan 1;25(1):1-18.

20 Nimmerjahn F, Ravetch JV. Fc-receptors as regulators of immunity. Adv Immunol. 2007; 96:179-204

21 Ben Mkaddem S, Benhamou M, Monteiro RC. Understanding Fc receptor involvement in inflammatory diseases: from mechanisms to new therapeutic tools. Front Immunol. 2019 Apr 12;10:811.

22 Mkaddem SB, Hayem G, Jönsson F, Rossato E, Boedec E, Boussetta T, et al. Shifting Fc $\gamma$ RIIA-ITAM from activation to inhibitory configuration ameliorates arthritis. J Clin Invest. 2014 Sep 2;124(9):3945-59.

23 Rossato E, Ben Mkaddem S, Kanamaru Y, Hurtado-Nedelec M, Hayem G, Descatoire V, et al. Reversal of arthritis by human monomeric IgA through the receptor-mediated SH2 domain-containing phosphatase 1 inhibitory pathway. Arthritis Rheumatol. $2015 \mathrm{Jul}$ 67(7):1766-77.

24 Kazatchkine MD, Kaveri SV. Immunomodulation of autoimmune and inflammatory diseases with intravenous immune globulin. N Engl J Med. 2001 Sep 6;345(10):747-55.

25 Nimmerjahn F, Ravetch JV. Anti-inflammatory actions of intravenous immunoglobulin. Annu Rev Immunol. 2008;26:513-33.

26 Zuercher AW, Spirig R, Baz Morelli A, Käsermann F. IVIG in autoimmune disease: potential next generation biologics. Autoimmun Rev. 2016 Aug;15(8):781-5.
27 Zuercher AW, Spirig R, Baz Morelli A, Rowe $T$, Käsermann F. Next-generation Fc receptor-targeting biologics for autoimmune diseases. Autoimmun Rev. 2019 Aug 9:18 (10):102366.

28 Ravetch JV, Bolland S. IgG Fc receptors. Annu Rev Immunol. 2001 Apr;19(1):275-90.

29 Nimmerjahn F, Ravetch JV. Fcy receptors as regulators of immune responses. Nat Rev Immunol. 2008 Jan;8(1):34-47.

30 Gierut A, Perlman H, Pope RM. Innate immunity and rheumatoid arthritis. Rheum Dis Clin North Am. 2010 May 1;36(2):271-96.

31 Hogarth PM, Pietersz GA. Fc receptor-targeted therapies for the treatment of inflammation, cancer and beyond. Nat Rev Drug Discov. 2012 Apr;11(4):311-31.

32 Wijngaarden S, Van Roon JA, Bijlsma JW, Van De Winkel JG, Lafeber FP. Fcgamma receptor expression levels on monocytes are elevated in rheumatoid arthritis patients with high erythrocyte sedimentation rate who do not use anti-rheumatic drugs. Rheumatology. 2003 May;42(5):681-8

33 Masuda M, Morimoto T, De Haas M Nishimura N, Nakamoto K, Okuda K, et al. Increase of soluble FcgRIIIa derived from natural killer cells and macrophages in plasma from patients with rheumatoid arthritis. J Rheumatol. 2003 Sep;30(9):1911-7.

34 Mullazehi M, Mathsson L, Lampa J, Rönnelid J. Surface-bound anti-type II collagen-containing immune complexes induce production of tumor necrosis factor $\alpha$, interleukin$1 \beta$, and interleukin- 8 from peripheral blood monocytes via $\mathrm{fc} \gamma$ receptor IIA: a potential pathophysiologic mechanism for humoral anti-type II collagen immunity in arthritis. Arthritis Rheum. 2006 Jun;54(6):1759-71

35 Clavel C, Nogueira L, Laurent L, Iobagiu C, Vincent $C$, Sebbag $M$, et al. Induction of macrophage secretion of tumor necrosis factor a through $F_{c} \gamma$ receptor IIa engagement by rheumatoid arthritis-specific autoantibodies to citrullinated proteins complexed with fibrinogen. Arthritis Rheum. 2008 Mar; 58(3):678-88

36 Mathsson L, Lampa J, Mullazehi M, Rönnelid J. Immune complexes from rheumatoid arthritis synovial fluid induce fcgammaRIIa dependent and rheumatoid factor correlated production of tumour necrosis factor-alpha by peripheral blood mononuclear cells. Arthritis Res Ther. 2006;8(3):R64.

37 Blom AB, Radstake TR, Holthuysen AE, Slöetjes AW, Pesman GJ, Sweep FG, et al. Increased expression of fcgamma receptors II and III on macrophages of rheumatoid arthritis patients results in higher production of tumor necrosis factor alpha and matrix metalloproteinase. Arthritis Rheum. 2003 Apr; 48(4):1002-14.

38 Magnusson SE, Engström M, Jacob U, Ulfgren AK, Kleinau S. High synovial expression of the inhibitory FegammaRIIb in rheumatoid arthritis. Arthritis Res Ther. 2007 Jun; 9(3):R51
39 Dougherty GJ, Selvendran Y, Murdoch S, Palmer DG, Hogg N. The human mononuclear phagocyte high-affinity $\mathrm{Fc}$ receptor, FcRI, defined by a monoclonal antibody, 10.1. Eur J Immunol. 1987;17(10):1453-9.

40 Rankin CT, Veri MC, Gorlatov S, Tuaillon N, Burke S, Huang L, et al. CD32B, the human inhibitory Fc-gamma receptor IIB, as a target for monoclonal antibody therapy of B-cell lymphoma. Blood. 2006 Oct;108(7):2384-91.

41 Kimberly RP, Edberg JC, Merriam LT, Clarkson SB, Unkeless JC, Taylor RP. In vivo handling of soluble complement fixing $\mathrm{Ab} / \mathrm{dsD}$ NA immune complexes in chimpanzees. J Clin Invest. 1989 Sep;84(3):962-70.

42 Clarkson SB, Bussel JB, Kimberly RP, Valinsky JE, Nachman RL, Unkeless JC. Treatment of refractory immune thrombocytopenic purpura with an anti-Fc gamma-receptor antibody. NEngl J Med. 1986 May 8;314(19):12369.

43 Rodeghiero F, Stasi R, Gernsheimer T, Michel M, Provan D, Arnold DM, et al. Standardization of terminology, definitions and outcome criteria in immune thrombocytopenic purpura of adults and children: report from an international working group. Blood. 2009 Mar 12;113(11):2386-93

44 Ericson SG, Coleman KD, Wardwell K, Baker S, Fanger MW, Guyre PM, et al. Monoclonal antibody 197 (anti-Fc $\gamma$ RI) infusion in a patient with immune thrombocytopenia purpura (ITP) results in down-modulation of Fc $\gamma \mathrm{R}$ on circulating monocytes. Br J Haematol. 1996 Feb;92(3):718-24.

45 Gelfand EW. Differences between IGIV products: impact on clinical outcome. Int Immunopharmacol. 2006 Apr;6(4):592-9.

46 Lazarus AH, Crow AR. Mechanism of action of IVIG and anti-D in ITP. Transfus Apher Sci. 2003 Jun;28(3):249-55.

47 Sewell WA, Jolles S. Immunomodulatory action of intravenous immunoglobulin. Immunology. 2002 Dec;107(4):387-93.

48 Etzioni A, Pollack S. High dose intravenous gammaglobulins in autoimmune disorders: mode of action and therapeutic uses. Autoimmunity. 1989 Jan;3(4):307-15.

49 Ballow M. The IgG molecule as a biological immune response modifier: mechanisms of action of intravenous immune serum globulin in autoimmune and inflammatory disorders. J Allergy Clin Immunol. $2011 \mathrm{Feb}$; 127(2):315-323.

50 Bussel J. Treatment of immune thrombocytopenic purpura in adults. Semin Hematol. 2006 Jul;43(3 Suppl 5):S3-10.

51 Leung DY. The immunologic effects of IVIG in Kawasaki disease. Int Rev Immunol. 1989 Jan;5(2):197-202.

52 Imbach P, Barandun S, d'Apuzzo V, Baumgartner C, Hirt A, Morell A, et al. Highdose intravenous gammaglobulin for idiopathic thrombocytopenic purpura in childhood. Lancet. 1981 Jun 6;1(8232):1228-31. 
53 Imbach $\mathrm{P}$, Wagner HP, Berchtold W, Gaedicke G, Hirt A, Joller P, et al. Intravenous immunoglobulin versus oral corticosteroids in acute immune thrombocytopenic purpura in childhood. Lancet. 1985 Aug 31;2(8453): 464-8.

54 Bussel JB, Kimberly RP, Inman RD, Schulman I, Cunningham-Rundles C, Cheung N, et al. Intravenous gammaglobulin treatment of chronic idiopathic thrombocytopenic purpura. Blood. 1983 Aug;62(2):480-6.

55 Newland AC, Treleaven JG, Minchinton RM, Waters AH. High-dose intravenous IgG in adults with autoimmune thrombocytopenia. Lancet. 1983 Jan 15;1(8316):84-7.

56 Fehr J, Hofmann V, Kappeler U. Transient reversal of thrombocytopenia in idiopathic thrombocytopenic purpura by high-dose intravenous gamma globulin. N Engl J Med. 1982 May 27;306(21):1254-8.

57 Branch DR. Unraveling the IVIG mystique. Transfusion. 2013 Feb;53(2):242-4.

58 Bussel JB. Fc receptor blockade and immune thrombocytopenic purpura. Semin Hematol. 2000 Jul;37(3):261-6.

59 Salama A, Mueller-Eckhardt C, Kiefel V. Effect of intravenous immunoglobulin in immune thrombocytopenia. Lancet. 1983 Jul 23; 322(8343):193-5.

60 Aloulou M, Ben Mkaddem S, Biarnes-Pelicot M, Boussetta T, Souchet H, Rossato E, et al. IgG1 and IVIg induce inhibitory ITAM signaling through $\mathrm{Fc} \gamma \mathrm{RIII}$ controlling inflammatory responses. Blood. 2012 Mar 29; 119(13):3084-96.

61 Burdach StEG, Evers KG, Geursen RG. Treatment of acute idiopathic thrombocytopenic purpura of childhood with intravenous immunoglobulin G: comparative efficacy of $7 \mathrm{~S}$ and 5S preparations. J Pediatr. 1986 Nov; 109(5):770-5.

62 Crow AR, Song S, Semple JW, Freedman J, Lazarus AH. IVIg inhibits reticuloendothelial system function and ameliorates murine passive-immune thrombocytopenia independent of anti-idiotype reactivity. Br J Haematol. 2001 Dec;115(3):679-86.

63 Von Gunten S, Schaub A, Vogel M, Stadler BM, Miescher S, Simon HU. Immunologic and functional evidence for anti-Siglec-9 autoantibodies in intravenous immunoglobulin preparations. Blood. 2006 Dec 15;108(13): 4255-9.

64 Von Gunten S, Vogel M, Schaub A, Stadler $\mathrm{BM}$, Miescher S, Crocker PR, et al. Intravenous immunoglobulin preparations contain anti-Siglec-8 autoantibodies. J Allergy Clin Immunol. 2007 Apr;119(4):1005-11.

65 Käsermann F, Boerema DJ, Rüegsegger M, Hofmann A, Wymann S, Zuercher AW, et al. Analysis and functional consequences of increased Fab-sialylation of intravenous immunoglobulin (IVIG) after lectin fractionation. PloS One. 2012;7(6):e37243.
66 Samuelsson A, Towers TL, Ravetch JV. Antiinflammatory activity of IVIG mediated through the inhibitory Fc receptor. Science. 2001 Jan 19;291(5503):484-6.

67 Schwab I, Nimmerjahn F. Role of sialylation in the anti-inflammatory activity of intravenous immunoglobulin: $\mathrm{F}\left(\mathrm{ab}^{\prime}\right)_{2}$ versus $\mathrm{Fc}$ sialylation. Clin Exp Immunol. 2014 Dec; 178(Suppl 1):97-9.

68 Schwab I, Mihai S, Seeling M, Kasperkiewicz M, Ludwig RJ, Nimmerjahn F. Broad requirement for terminal sialic acid residues and Fc $\gamma$ RIIB for the preventive and therapeutic activity of intravenous immunoglobulins in vivo. Eur J Immunol. 2014 May;44(5):1444-53.

69 Leontyev D, Katsman Y, Branch DR. Mouse background and IVIG dosage are critical in establishing the role of inhibitory Fc $\gamma$ receptor for the amelioration of experimental ITP. Blood. 2012 May 31;119(22):5261-4.

70 Siragam V, Crow AR, Brinc D, Song S, Freedman J, Lazarus AH. Intravenous immunoglobulin ameliorates ITP via activating $\mathrm{Fc}$ gamma receptors on dendritic cells. Nat Med. 2006 Jun;12(6):688-92

71 Bazin R, Lemieux R, Tremblay T. Reversal of immune thrombocytopenia in mice by crosslinking human immunoglobulin $G$ with a high-affinity monoclonal antibody. Br J Haematol. 2006 Oct;135(1):97-100.

72 Crow AR, Lazarus AH. Mechanistic properties of intravenous immunoglobulin in murine immune thrombocytopenia: support for Fc $\gamma$ RIIB falls by the wayside. Semin Hematol. 2016 Apr;53(Suppl 1):S20-2.

73 Kaneko Y, Nimmerjahn F, Ravetch JV. Antiinflammatory activity of immunoglobulin G resulting from $\mathrm{Fc}$ sialylation. Science. 2006 Aug 4;313(5787):670-3.

74 Anthony RM, Nimmerjahn F, Ashline DJ, Reinhold VN, Paulson JC, Ravetch JV. Recapitulation of IVIG anti-inflammatory activity with a recombinant IgG Fc. Science. $2008 \mathrm{Apr}$ 18:320(5874):373-6.

75 Schwab I, Nimmerjahn F. Intravenous immunoglobulin therapy: how does IgG modulate the immune system? Nat Rev Immunol. 2013 Mar;13(3):176-89.

76 Galeotti C, Stephen-Victor E, Karnam A, Das M, Gilardin L, Maddur MS, et al. Intravenous immunoglobulin induces IL-4 in human basophils by signaling through surface-bound IgE. J Allergy Clin Immunol. 2019 Aug; 144(2):524-35.e8.

77 Leontyev D, Neschadim A, Branch DR. Cytokine profiles in mouse models of experimental immune thrombocytopenia reveal a lack of inflammation and differences in response to intravenous immunoglobulin depending on the mouse strain. Transfusion. $2014 \mathrm{Nov}$ 54(11):2871-9.

78 Campbell IK, Miescher S, Branch DR, Mott PJ, Lazarus AH, Han D, et al. Therapeutic effect of IVIG on inflammatory arthritis in mice is dependent on the Fc portion and independent of sialylation or basophils. J Immunol. 2014 Jun 1;192(11):5031-8.
79 Lewis BJB, Leontyev D, Neschadim A, Blacquiere M, Branch DR. GM-CSF and IL-4 are not involved in IVIG-mediated amelioration of ITP in mice: a role for IL-11 cannot be ruled out. Clin Exp Immunol. 2018 Sep;193(3):293301.

80 Crow AR, Song S, Semple JW, Freedman J, Lazarus AH. A role for IL-1 receptor antagonist or other cytokines in the acute therapeutic effects of IVIg? Blood. 2007 Jan; 109(1): $155-8$.

81 Bozza S, Käsermann F, Kaveri SV, Romani L, Bayry J. Intravenous immunoglobulin protects from experimental allergic bronchopulmonary aspergillosis via a sialylation-dependent mechanism. Eur J Immunol. 2019 Jan; 49(1):195-8.

82 Leontyev D, Katsman Y, Ma XZ, Miescher S, Käsermann F, Branch DR. Sialylation-independent mechanism involved in the amelioration of murine immune thrombocytopenia using intravenous gammaglobulin. Transfusion. 2012 Aug;52(8):1799-805.

83 Guhr T, Bloem J, Derksen NI, Wuhrer M, Koenderman AH, Aalberse RC, et al. Enrichment of sialylated IgG by lectin fractionation does not enhance the efficacy of immunoglobulin $G$ in a murine model of immune thrombocytopenia. PloS One. 2011;6(6): e21246.

84 Ogata S, Shimizu C, Franco A, Touma R, Kanegaye JT, Choudhury BP, et al. Treatment response in Kawasaki disease is associated with sialylation levels of endogenous but not therapeutic intravenous immunoglobulin G. PloS One. 2013 Dec 6;8(12):e81448.

85 Nagelkerke SQ, Dekkers G, Kustiawan I, van de Bovenkamp FS, Geissler J, Plomp R, et al. Inhibition of $\mathrm{F} c \gamma \mathrm{R}$-mediated phagocytosis by IVIg is independent of IgG-Fc sialylation and Fc $\gamma$ RIIb in human macrophages. Blood. 2014 Dec 11;124(25):3709-18.

86 Othy S, Topçu S, Saha C, Kothapalli P, Lacroix-Desmazes $\mathrm{S}$, Käsermann $\mathrm{F}$, et al. Sialylation may be dispensable for reciprocal modulation of helper $\mathrm{T}$ cells by intravenous immunoglobulin. Eur J Immunol. 2014 Jul:44(7):2059-63.

87 Temming AR, Dekkers G, van de Bovenkamp FS, Plomp HR, Bentlage AEH, Szittner Z, et al. Human DC-SIGN and CD23 do not interact with human IgG. Sci Rep. 2019 Jul10; 9(1):9995.

88 Maddur MS, Stephen-Victor E, Das M, Prakhar P, Sharma VK, Singh V, et al. Regulatory $\mathrm{T}$ cell frequency, but not plasma IL-33 levels, represents potential immunological biomarker to predict clinical response to intravenous immunoglobulin therapy. J Neuroinflammation. 2017 Mar 20;14(1):58.

89 von Gunten S, Shoenfeld Y, Blank M, Branch DR, Vassilev T, Käsermann F, et al. IVIG pluripotency and the concept of Fc-sialylation: challenges to the scientist. Nat Rev Immunol. 2014 April;14(5):349.
Animal Models of RA Used to Assess

Treatment Modalities
Pharmacology 2020;105:618-629 DOI: $10.1159 / 000508239$ 
90 Trinath J, Hegde P, Sharma M, Maddur MS, Rabin M, Vallat JM, et al. Intravenous immunoglobulin expands regulatory $\mathrm{T}$ cells via induction of cyclooxygenase-2-dependent prostaglandin E2 in human dendritic cells. Blood. 2013 Aug 22;122(8):1419-27.

91 Wiedeman AE, Santer DM, Yan W, Miescher S, Käsermann F, Elkon KB. Contrasting mechanisms of interferon- $\alpha$ inhibition by intravenous immunoglobulin after induction by immune complexes versus Tolllike receptor agonists. Arthritis Rheum. 2013 Oct;65(10):2713-23.

92 Das M, Karnam A, Stephen-Victor E, Gilardin L, Bhatt B, Kumar Sharma V, et al. Intravenous immunoglobulin mediates anti-inflammatory effects in peripheral blood mononuclear cells by inducing autophagy. Cell Death Dis. 2020 Jan 23;11(1):50.

93 Provan D, Stasi R, Newland AC, Blanchette VS, Bolton-Maggs P, Bussel JB, et al. International consensus report on the investigation and management of primary immune thrombocytopenia. Blood. 2010 Jan 14; 115(2):168-86.

94 Orbach H, Katz U, Sherer Y, Shoenfeld Y. Intravenous immunoglobulin: adverse effects and safe administration. Clin Rev Allergy Immunol. 2005 Ded;29(3):173-84.

95 Branch DR. Anti-A and anti-B: what are they and where do they come from? Transfusion. 2015 Jul;55(S2):S74-9.

96 Pendergrast J, Willie-Ramharack K, Sampson L, Laroche V, Branch DR. The role of inflammation in intravenous immune globulin-mediated hemolysis. Transfusion. 2015 Jul;55(Suppl 2):S65-73.

97 Pendergrast J, Binnington B, Tong TN, Callum J, Cserti-Gazdewich CM, Lau W, et al. Incidence and risk factors for IVIG-mediated hemolysis. Blood. 2017;130:2398.

98 Branch DR, Hellberg A, Bruggeman CW, Storry JR, Sakac D, Blacquiere M, et al. ABO zygosity, but not secretor or $\mathrm{Fc}$ receptor status, is a significant risk factor for IVIGassociated hemolysis. Blood. 2018 Feb 15; 131(7):830-5.

99 Guo Y, Tian X, Wang X, Xiao Z. Adverse effects of immunoglobulin therapy. Front Immunol. 2018 Jun 8;9:1299.

100 Zuercher A, Berger M, Bolli R, Vonarburg C, Spycher M, Shebl A, et al. Plasma-derived immunoglobulins. In: Parnham MJ, Nijkamp FP, Rossi A, editors. Nijkamp and Parnham's Principles of Immunopharmacology. Cham: Springer; 2019. p. 327-68.

101 Glauser W. Why do Canadians use so much plasma? Can Med Assoc J. 2014 Oct 7; 186(14):1054.

102 Gelfand EW. Intravenous immune globulin in autoimmune and inflammatory diseases. N Engl J Med. 2012 Nov 22;368(8):777-25.

103 Katz-Agranov N, Khattri S, Zandman-Goddard G. The role of intravenous immunoglobulins in the treatment of rheumatoid arthritis. Autoimmun Rev. 2015 Aug 1; 14(8):651-8.
104 Kanik KS, Yarboro CH, Naparstek Y, Plotz $\mathrm{PH}$, Wilder RL. Failure of low-dose intravenous immunoglobulin therapy to suppress disease activity in patients with treatmentrefractory rheumatoid arthritis. Arthritis Rheum. 1996 Jun;39(6):1027-9.

105 Maksymowych WP, Aviña-Zubieta A, Luong M, Russell AS. High dose intravenous immunoglobulin (IVIg) in severe refractory rheumatoid arthritis: no evidence for efficacy. Clin Exp Rheumatol. 1996 Nov-Dec; 14(6):657-60.

106 Muscat C, Bertotto A, Ercolani R, Bistoni O, Agea E, Cesarotti M, et al. Long term treatment of rheumatoid arthritis with high doses of intravenous immunoglobulins: effects on disease activity and serum cytokines. Ann Rheum Dis. 1995 May;54(5):382-5.

107 Vaitla PM, McDermott EM. The role of high-dose intravenous immunoglobulin in rheumatology. Rheumatology. 2010 Jun 1; 49(6):1040-8.

108 Prieur AM, Adleff A, Debre M, Boulate P, Griscelli C. High dose immunoglobulin therapy in severe juvenile chronic arthritis: long-term follow-up in 16 patients. Clin Exp Rheumatol. 1990 Nov-Dec;8(6):603-8.

109 Tumiati B, Casoli P, Veneziani M, Rinaldi G. High-dose immunoglobulin therapy as an immunomodulatory treatment of rheumatoid arthritis. Arthritis Rheum. 1992 Oct; 35(10):1126-33.

110 Lewis BJB, Ville J, Blacquiere M, Cen S, Spirig $\mathrm{R}$, Zuercher $\mathrm{AW}$, et al. Using the $\mathrm{K} / \mathrm{BxN}$ mouse model of endogenous, chronic, rheumatoid arthritis for the evaluation of potential immunoglobulin-based therapeutic agents, including IVIg and Fc- $\mu$ TP-L309C, a recombinant IgG1 Fc hexamer. BMC Immunol. 2019 Dec;20(1):44.

111 Zhang X, Owens J, Olsen HS, So E, Burch E, McCroskey MC, et al. A recombinant human IgG1 Fc multimer designed to mimic the active fraction of IVIG in autoimmunity. JCI Insight. 2019 Jan 24;4(2):e121905.

112 Washburn N, Schwab I, Ortiz D, Bhatnagar N, Lansing JC, Medeiros A, et al. Controlled tetra-Fc sialylation of IVIg results in a drug candidate with consistent enhanced anti-inflammatory activity. Proc Natl Acad Sci U S A. 2015 Mar 17;112(11):E1297-306.

113 Holmdahl R, Bockermann R, Bäcklund J, Yamada $\mathrm{H}$. The molecular pathogenesis of collagen-induced arthritis in mice: a model for rheumatoid arthritis. Ageing Res Rev. 2002 Feb;1(1):135-47.

114 Kannan K, Ortmann RA, Kimpel D. Animal models of rheumatoid arthritis and their relevance to human disease. Pathophysiology. 2005 Oct;12(3):167-81.

115 Brand DD, Latham KA, Rosloniec EF. Collagen-induced arthritis. Nat Protoc. 2007 May;2(5):1269, 75.
116 Inglis JJ, Criado G, Medghalchi M, Andrews M, Sandison A, Feldmann M, et al. Collageninduced arthritis in C57BL/6 mice is associated with a robust and sustained T-cell response to type II collagen. Arthritis Res Ther. 2007;9(5):R113.

117 McNamee K, Williams R, Seed M. Animal models of rheumatoid arthritis: how informative are they? Eur J Pharmacol. $2015 \mathrm{Jul}$ 15;759:278-86.

118 Mitamura M, Nakano N, Yonekawa T, Shan L, Kaise T, Kobayashi T, et al. T cells are involved in the development of arthritis induced by anti-type II collagen antibody. Int Immunopharmacol. 2007 Oct;7(10):13608.

119 Nandakumar KS, Bäcklund J, Vestberg M, Holmdahl R. Collagen type II (CII)-specific antibodies induce arthritis in the absence of $\mathrm{T}$ or B cells but the arthritis progression is enhanced by CII-reactive T cells. Arthritis Res Ther. 2004 Oct 1;6(6):R544-50.

120 Nandakumar KS, Holmdahl R. Efficient promotion of collagen antibody induced arthritis (CAIA) using four monoclonal antibodies specific for the major epitopes recognized in both collagen induced arthritis and rheumatoid arthritis. J Immunol Methods. 2005 Sep 1;304(1-2):126-36.

121 Khachigian LM. Collagen antibody-induced arthritis. Nat Protoc. 2006 Dec; 1(5):2512-6.

122 Banda NK, Hyatt S, Antonioli AH, White JT, Glogowska M, Takahashi K, et al. Role of C3a receptors, C5a receptors, and complement protein $\mathrm{C} 6$ deficiency in collagen antibody-induced arthritis in mice. J Immunol. 2012 Feb 1;188(3):1469-78.

123 Daha NA, Banda NK, Roos A, Beurskens FJ, Bakker JM, Daha MR, et al. Complement activation by (auto-) antibodies. Mol Immunol. 2011 Aug 1;48(14):1656-65.

124 Williams RO, Feldmann M, Maini RN. Cartilage destruction and bone erosion in arthritis: the role of tumour necrosis factor alpha. Ann Rheum Dis. 2000 Nov 1; 59(90001):i75-80.

125 Li P, Schwarz EM. The TNF-alpha transgenic mouse model of inflammatory arthritis. Springer Semin Immunopathol. 2003 Aug; 25(1):19-33.

126 Aidinis V, Plows D, Haralambous S, Armaka M, Papadopoulos P, Kanaki MZ, et al. Functional analysis of an arthritogenic synovial fibroblast. Arthritis Res Ther. 2003 Jun 1; 5(3):R140-57.

127 Guo Q, Wang Y, Xu D, Nossent J, Pavlos NJ, $\mathrm{Xu}$ J. Rheumatoid arthritis: pathological mechanisms and modern pharmacologic therapies. Bone Res. 2018 Apr 27;6(1):15.

128 Kouskoff V, Korganow AS, Duchatelle V, Degott C, Benoist C, Mathis D. Organ-specific disease provoked by systemic autoimmunity. Cell. 1996 Nov 29;87(5):811-22.

129 Ditzel HJ. The K/BxN mouse: a model of human inflammatory arthritis. Trends $\mathrm{Mol}$ Med. 2004 Jan;10(1):40-5. 
130 Mangialaio S, Ji H, Korganow AS, Kouskoff $\mathrm{V}$, Benoist C, Mathis D. The arthritogenic T cell receptor and its ligand in a model of spontaneous arthritis. Arthritis Rheum. 1999 Dec;42(12):2517-23.

131 Ji H, Gauguier D, Ohmura K, Gonzalez A, Duchatelle V, Danoy P, et al. Genetic influences on the end-stage effector phase of arthritis. J Exp Med. 2001 Aug 6;194(3):32130.

132 Monach PA, Mathis D, Benoist C. The K/ BxN arthritis model. Curr Protoc Immunol. 2008 May; 15(1):22.

133 Monach P, Hattori K, Huang H, Hyatt E, Morse J, Nguyen L, et al. The $\mathrm{K} / \mathrm{BxN}$ mouse model of inflammatory arthritis: theory and practice. Arthritis Res. 2007;136:269-82.

134 Debré M, Bonnet MC, Fridman WH, Carosella E, Philippe N, Reinert P, et al. Infusion of Fc gamma fragments for treatment of children with acute immune thrombocytopenic purpura. Lancet. 1993 Oct 16; 342(8877):945-9.

135 Hsu CH, Chen MR, Hwang FY, Kao HA, Hung HY, Hsu CH. Efficacy of plasmintreated intravenous gamma-globulin for therapy of Kawasaki syndrome. Pediatr Infect Dis J. 1993 Jun;12(6):509-12.

136 Miescher SM, Käsermann F. The future of immunoglobulin therapy: an overview of the 2nd international workshop on natural antibodies in health and disease. Autoimmun Rev. 2013 Apr;12(6):639-42.

137 Basta M, Branch DR. 7th international immunoglobulin conference: mechanisms of action. Clin Exp Immunol. 2014 Dec; 178(Suppl 1):87-8.

138 Bosques CJ, Manning AM. Fc-gamma receptors: attractive targets for autoimmune drug discovery searching for intelligent therapeutic designs. Autoimmun Rev. 2016 Nov; 15(11):1081-8.

139 Stephen-Victor E, Bayry J. Multimerized IgG1 Fc molecule as an anti-inflammatory agent. Nat Rev Rheumatol. 2018 Jul; 14(7):390-2.

140 Czajkowsky DM, Hu J, Shao Z, Pleass RJ. Fcfusion proteins: new developments and future perspectives. EMBO Mol Med. 2012 Oct 1;4(10):1015-28.
141 Jain A, Olsen HS, Vyzasatya R, Burch E, Sakoda Y, Mérigeon EY, et al. Fully recombinant IgG2a Fc multimers (stradomers) effectively treat collagen-induced arthritis and prevent idiopathic thrombocytopenic purpura in mice. Arthritis Res Ther. 2012 Aug; 14(4):R192.

142 Niknami M, Wang MX, Nguyen T, Pollard JD. Beneficial effect of a multimerized immunoglobulin $\mathrm{Fc}$ in an animal model of inflammatory neuropathy (experimental autoimmune neuritis). J Peripher Nerv Syst. 2013 Jun;18(2):141-52.

143 Thiruppathi M, Sheng JR, Li L, Prabhakar BS, Meriggioli MN. Recombinant IgG2a Fc (M045) multimers effectively suppress experimental autoimmune myasthenia gravis. J Autoimmun. 2014 Aug;52:64-73.

144 Ortiz DF, Lansing JC, Rutitzky L, Kurtagic E, Prod'homme T, Choudhury A, et al. Elucidating the interplay between IgG-Fc valency and $\mathrm{F} c \gamma \mathrm{R}$ activation for the design of immune complex inhibitors. Sci Transl Med. 2016 Nov 16;8(365):365ra158.

145 Ridgway JB, Presta LG, Carter P. "Knobsinto-holes" engineering of antibody $\mathrm{CH} 3$ domains for heavy chain heterodimerization. Protein Eng Des Sel. 1996 Jul 1; 9(7):617-21.

146 Smith RI, Morrison SL. Recombinant polymeric IgG: an approach to engineering more potent antibodies. Biotechnology. 1994 Jul; 12(7):683-8

147 Czajkowsky DM, Andersen JT, Fuchs A, Wilson TJ, Mekhaiel D, Colonna M, et al. Developing the IVIG biomimetic, Hexa-Fc, for drug and vaccine applications. Sci Rep. 2015 Apr 27;5:9526.

148 Blundell PA, Le NPL, Allen J, Watanabe Y, Pleass RJ. Engineering the fragment crystallizable $(\mathrm{Fc})$ region of human IgG1 multimers and monomers to fine-tune interactions with sialic acid-dependent receptors. J Biol Chem. 2017 Aug 4;292(31):12994-3007.
149 Qureshi OS, Rowley TF, Junker F, Peters SJ, Crilly S, Compson J, et al. Multivalent Fc $\gamma$ receptor engagement by a hexameric $\mathrm{Fc}$-fusion protein triggers $\mathrm{F} c \gamma$-receptor internalisation and modulation of $\mathrm{F} c \gamma$-receptor functions. Sci Rep. 2017 Dec 6;7(1):17049-5.

150 Zhou H, Olsen H, So E, Mérigeon E, Rybin $\mathrm{D}$, Owens J, et al. A fully recombinant human IgG1 Fc multimer (GL-2045) inhibits complement-mediated cytotoxicity and induces iC3b. Blood Adv. 2017 Mar 14 1(8):504-15.

151 Sun H, Olsen HS, Mérigeon EY, So E, Burch E, Kinsey S, et al. Recombinant human IgG1 based Fc multimers, with limited FcR binding capacity, can effectively inhibit complement-mediated disease. J Autoimmun. 2017 Nov 1;84:97-108.

152 Spirig R, Campbell IK, Koernig S, Chen CG, Lewis BJB, Butcher R, et al. rIgG1 Fc hexamer inhibits antibody-mediated autoimmune disease via effects on complement and Fc $\gamma$ Rs. J Immunol. 2018 Apr 15;200(8):254253.

153 Bach JF. The effect of infections on susceptibility to autoimmune and allergic diseases. N Engl J Med. 2002 Sep 19;347(12):911-20.

154 Eaton WW, Rose NR, Kalaydjian A, Pedersen MG, Mortensen PB. Epidemiology of autoimmune diseases in Denmark. J Autoimmun. 2007 Aug 1;29(1):1-9.

155 Vento S, Cainelli F. Autommune diseases in low and middle income countries: a neglected issue in global health. Isr Med Assoc J. 2016 Jan 1;18(1):54-5.

156 Ardern-Jones MR, Venning VA, Wojnarowska F. Oral and topical corticosteroids in bullous pemphigoid. N Engl J Med. 2002 Jul 5;347(2):143-5.

157 Nimmerjahn F, Ravetch JV. Antibody-mediated modulation of immune responses. Immunol Rev. 2010 Jul;236(1):265-75.

158 Tsuboi N, Ernandez T, Li X, Nishi H, Cullere $\mathrm{X}$, Mekala D, et al. Regulation of human neutrophil $\mathrm{Fc} \gamma$ receptor IIa by C5a receptor promotes inflammatory arthritis in mice. Arthritis Rheum. 2011 Feb;63(2):467-78. 